\title{
ANALISIS DAN PEMODELAN PENDAPATAN PEKERJA PEREMPUAN DI INDONESIA MENGGUNAKAN DATA PANEL
}

\author{
(Analysis and Modeling Income of Women Workers in Indonesia \\ Using Panel Data)
}

\author{
Devaki Areta Putrie', Arif Rahman² \\ Badan Pusat Statistik Kabupaten Sekadau ${ }^{1,2}$ \\ Jl Merdeka Timur Km 9.0 Kompleks Perkantoran Pemda Sekadau \\ E-mail: devaki.areta@bps.go.id
}

\begin{abstract}
ABSTRAK
Pemberdayaan wanita merupakan salah satu tujuan yang ingin dicapai banyak negara di dunia. Indeks pemberdayaan Gender adalah indkator yang menunjukkan seberapa berdaya perempuan di suatu wilayah. Salah satu komponen untuk mengukur Indeks Pemberdayaan Gender di Indonesia yang masih timpang ialah sumbangan pendapatan wanita. Pendapatan pekerja perempuan masih terpaut cukup jauh dengan pekerja laki-laki. Penelitian ini mencoba untuk menganalisis dan memodelkan pendapatan pekerja perempuan dari 34 provinsi di Indonesia dari tahun 2015 hingga 2018 menggunakan regresi data panel. Model yang terpilih pada penelitian ini adalah fixed effect model. Model diperlakukan sebagai SUR dan diestimasi dengan feasible generalized least square karena terdapat masalah heteroskedastisitas dan cross-sectional correlation. Hasil penelitian menunjukkan bahwa variabel IPM perempuan, PDRB, dan proporsi perempuan bekerja berpengaruh signifikan terhadap pendapatan pekerja perempuan suatu provinsi.
\end{abstract}

Kata kunci: pendapatan pekerja wanita, pemberdayaan wanita, regresi data panel, fixed effect model.

\begin{abstract}
Women empowerment is one of the goals that many countries in the world want to achieve. Gender Empowerment Index is an indicator that shows how empowered women are in a region. One of the dimension to measure the Gender Empowerment Index which still unequal in Indonesia is women's income contibution. The income of female workers is quite far from the male workers. This study attempts to analyze and form a model for income of female workers from 34 provinces in Indonesia from 2015 to 2018 using panel data regression. The model chosen in this study is the fixed effect model. The model is treated as SUR and estimated with feasible generalized least square because there are heteroscedasticity and crosssectional correlation. The results showed that the variables of women's HDI, GRDP, and the proportion of working women had a significant effect on the income of female workers.
\end{abstract}

Keywords: income of female workers, women empowerment, panel data regression, fixed effect model.

\section{PENDAHULUAN}

Di masa pandemi ini, PBB mencatat bahwa kekerasan domestik terhadap perempuan mengalami peningkatan yang signifikan. Di beberapa negara, peningkatan tersebut bisa mencapai sekitar 30 persen. Hal ini merupakan sebuah kemunduran bagi pencapaian goal ke-5 SDGs yakni pencapaian kesetaraan gender dan memberdayakan seluruh wanita dan anak perempuan.

Salah satu indikator untuk mengukur pemberdayaan wanita ialah Indeks Pemberdayaan Gender atau IDG. IDG mengukur ketimpangan gender melalui tiga dimensi yakni dimensi ekonomi, dimensi pengambilan keputusan, dan dimensi partisipasi politik. Salah satu komponen pembentuk IDG yang masih sangat timpang ialah sumbangan pendapatan perempuan. Di Indonesia, sumbangan pendapatan perempuan selalu lebih rendah dibandingkan dengan laki-laki. BPS mencatat bahwa sumbangan pendapatan perempuan hanya sebesar 36,70 pada tahun 2018 . 
Berdasarkan data rata-rata upah buruh/karyawan di Indonesia pada tahun 2018, pekerja perempuan hanya mendapat sekitar 7.826 rupiah untuk setiap 10.000 rupiah yang didapatkan pekerja laki-laki. Selain itu, selisih dari pendapatan pekerja laki-laki dan perempuan cenderung mengalami kenaikan selama lima tahun terakhir (lihat Gambar 1).

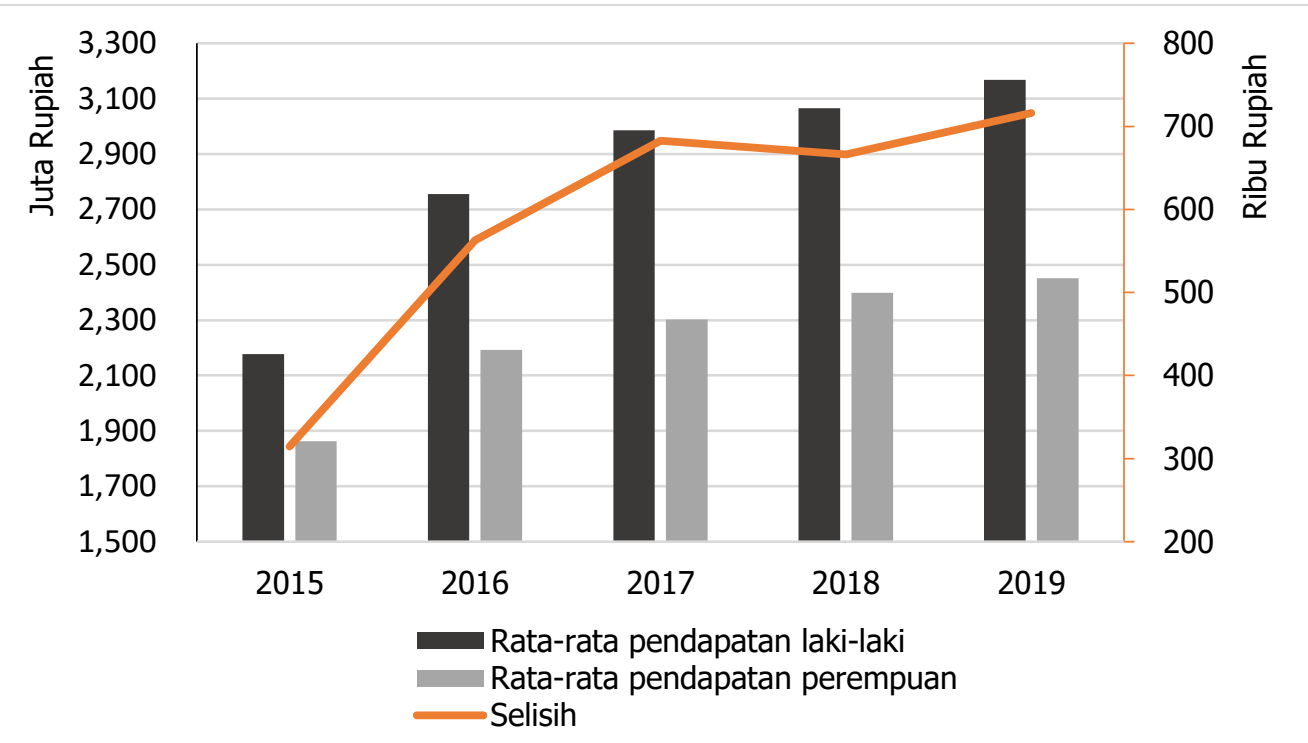

Sumber: Publikasi Keadaan Angkatan Kerja di Indonesia Agustus (diolah)

Gambar 58. Selisih pendapatan pekerja laki-laki dan perempuan di Indonesia, Tahun 2015-2019.

Kesenjangan upah berdasarkan gender adalah hal nyata yang merugikan kaum perempuan dengan menekan pendapatan mereka. Upaya untuk mengatasi kesenjangan upah antara dua gender harus mampu memeriksa dimana perekonomian suatu daerah memberikan peluang yang tidak setara bagi permpuan di setiap level pendidikan dan pilihan karir (Schieder \& Gould, 2016)

Lebih jauh lagi, perempuan yang memiliki pendapatan sendiri akan memiliki lebih banyak pilihan. Ketika memiliki distribusi yang cukup besar pada ekonomi keluarga, seorang wanita bisa jadi akan ikut berperan dalam pengambilan keputusan dalam rumah tangganya. Mengaitkan dengan meningkatnya kasus kekerasan yang telah disebutkan di awal, perempuan yang memiliki pendapatan sendiri juga cenderung lebih mudah untuk meninggalkan pasangannya ketika mengalami kekerasan domestik yang sudah di luar kendali. Oleh sebab itu, pembahasan mengenai pendapatan pekerja perempuan menjadi penting untuk dilakukan.

Analisis terhadap pendapatan pekerja pekerja perempuan telah dilakukan oleh Christoper dkk. Hasil penelitian tersebut menunjukkan bahwa tingkat pendidikan dan jumlah jam kerja berpengaruh positif terhadap pendapatan pekerja wanita dari rumah tangga miskin (Christoper et al., 2019). Penelitian lain yang menganalisis determinan pendapatan pekerja wanita juga dilakukan oleh Huruta dkk dengan metode analisis regresi berganda. Penelitian ini menunjukkan bahwa secara parsial, usia dan level pendidikan memiliki pengaruh positif dan signifikan terhadap pendapatan pekerja wanita, sementara jumlah anggota keluarga, status pernikahan, dan lapangan pekerjaan tidak berpengaruh secara signifikan (Huruta et al., 2019). Penghasilan perempuan tidak selalu menjamin pemberdayaan, terutama ketika upah berada di level yang rendah (Bhattacharjee \& Goswami, 2020). Penelitian lain menunjukkan bahwa usia dan tingkat pendidikan berpengaruh pada pendapatan added workeri pada wanita menikah, sementara keberadaan anak usia 0-14 tahun dan pendidikan suami tidak berpengaruh signifikan (Febriani \& Saleh, 2016).

Berdasarkan uraian di atas, penelitian ini bertujuan untuk menggambarkan pendapatan pekerja perempuan di 34 provinsi di Indonesia. Selain itu, penelitian ini juga akan membangun model statistik yang akan digunakan untuk menganalisis faktor-faktor yang memengaruhi pendapatan pekerja perempuan di Indonesia periode 2015-2018 menggunakan variabel proporsi perempuan yang menikah muda, IPM perempuan, PDRB, proporsi wanita bekerja, serta angkatan kerja perempuan. 


\section{METODE}

\subsection{Metode Pengumpulan Data}

Penelitian ini menggunakan data panel, yakni data cross-section yang dikumpulkan selama periode waktu tertentu sehingga memiliki dimensi ruang dan waktu. Data panel terdiri dari balanced panel dan unbalanced panel. Data panel dikatakan balanced apabila setiap unit crosssection memiliki jumlah observasi time-series yang sama dan dikatakan unbalanced apabila setiap unit cross-section memiliki jumlah observasi time-series yang tidak sama (Greene, 2012).

Penelitian ini menggunakan balanced panel data dari 34 provinsi di Indonesia selama tahun 2015 hingga 2018 sehingga secara total, terdapat 136 observasi. Varibel yang digunakan didapatkan dari data sekunder pada tabel dinamis maupun publikasi BPS. Varibel tersebut antara lain:

- Pendapatan pekerja perempuan (ribu rupiah) yang didapatkan dari rata-rata upah/gajii bersih buruh/karyawan perempuan selama sebulan pada publikasi Keadaan Angkatan Kerja Agustus tahun 2015-2018.

- Proporsi perempuan menikah muda (persen) yang didapatkan dari proporsi perempuan usia 20-24 tahun yang berstatus menikah atau hidup bersama di bawah usia 18 tahun dari tabel dinamis BPS.

- IPM perempuan dan PDRB (milyar rupiah) masing-masing provinsi di Indonesia yang didapatkan dari tabel dinamis BPS.

- Proporsi perempuan bekerja (persen) dan jumlah angkatan kerja perempuan (ribu orang) yang didapatkan dari publikasi Keadaan Angkatan Kerja Agustus tahun 2015-2018.

\subsection{Metode Analisis}

Analisis dalam penelitian ini terdiri dari analisis deskriptif dan analisis inferensia. Analisis deskriptif dalam penelitian ini bertujuan untuk mendapatkan gambaran pendapatan pekerja perempuan pada 34 provinsi di Indonesia periode 2015-2018. Analisis inferensia dalam penelitian ini bertujuan untuk mengkaji pengaruh variabel independen terhadap rata-rata pendapatan pekerja wanita pada 34 provinsi di Indonesia periode 2015-2018. Analisis yang diterapkan adalah analisis regresi data panel dengan metode estimasi least square. Persamaan regresi data panel yang digunakan dalam penelitian ini adalah:

$$
\mathrm{PP}_{\mathrm{it}}=\alpha+\beta_{1} \mathrm{MAR}_{\mathrm{it}}+\beta_{2} \mathrm{IPM}_{\mathrm{it}}+\beta_{3} \mathrm{PDRB}_{\mathrm{it}}+\beta_{4} \mathrm{FW}_{\mathrm{it}}+\beta_{5} \mathrm{AKP}_{\mathrm{it}}+\mathrm{u}_{\mathrm{it}}
$$

dimana:

$\begin{array}{ll}\mathrm{i} & =\text { provinsi } \\ \mathrm{t} & =\text { tahun } \\ \mathrm{a} & =\text { intersep } \\ \text { PP } & =\text { pendapatan pekerja perempuan } \\ \text { MAR } & =\text { proporsi perempuan menikah muda } \\ \mathrm{IPM} & =\text { IPM perempuan } \\ \text { PDRB } & =\text { Produk Domestik Regional Bruto } \\ \text { FW } & =\text { proporsi perempuan bekerja } \\ \text { AKP } & =\text { angkatan kerja perempuan } \\ \beta_{1}, \beta_{2}, \ldots, \beta_{5} & =\text { koefisien variabel bebas } \\ \mathrm{u}_{\mathrm{it}} & =\text { error term }\end{array}$

Model regresi data panel terbagi menjadi tiga yaitu pooled regression model, fixed effect model (FEM), dan random effect model (REM). Persamaan model tersebut selanjutnya akan dimodifikasi sesuai dengan model terbaik. Sehingga langkah selanjutnya adalah pemilihan model paling tepat untuk data panel. Untuk mengecek apakah model terbaik adalah pooled regression atau fixed effect model digunakan uji Chow. Untuk mengecek apakah model terbaik adalah random effect model atau fixed effect model digunakan uji Hausman. Untuk mengecek apakah 
model terbaik adalah pooled regression atau random effect model digunakan uji Breusch-Pagan Lagrange Multiplier.

Apabila model yang terpilih adalah pooled regression atau fixed effect model maka perlu dilakukan pengecekan terhadap asumsi homoskedastisitas dan pengecekan adanya crosssectional correlation untuk mengetahui apakah OLS adalah metode estimasi yang tepat. Apabila model yang terpilih adalah random effect mode/ maka GLS adalah metode estimasi yang tepat.

Selanjutnya, dilakukan uji keberartian model dengan melihat nilai koefisien determinasi, uji $F$ dan uji t. Koefisien determinasi digunakan untuk mengukur proporsi dari total variasi variabel terikat yang mampu dijelaskan oleh variabel bebas dalam model regresi. Uji F digunakan untuk menguji signifikansi persamaan regresi secara keseluruhan. Uji t digunakan untuk menguji apakah suatu variabel bebas berpengaruh signifikan terhadap variabel terikat secara parsial.

Setelah pengujian keberartian model, dilakukan pengujian asumsi klasik regresi linier pada model yang terbentuk. Asumsi tersebut yaitu normalitas, nonmultikolinieritas, nonautokorelasi dan homoskedastisitas. Apabila model terpilih adalah pooled regression atau fixed effect model maka pengecekan asumsi homoskedastisitas telah dilakukan pada pemilihan model terbaik.

\section{HASIL DAN PEMBAHASAN}

\subsection{Gambaran Pendapatan Pekerja Wanita di Indonesia}

Pengembangan peran ekonomi wanita merupakan langkah awal yang diharapkan dapat mewujudkan pemberdayaan kaum perempuan. Ada banyak alasan mengapa seorang perempuan perlu untuk memiliki penghasilan sendiri. Perempuan dengan pendapatan sendiri dapat mendongkrak finansial keluarga, memiliki lebih banyak opsi sosial dan ekonomi, meningkatkan kepercayaan diri, serta berdaya saing. Hal-hal tersebut pada akhirnya bisa jadi akan mengecilkan risiko seorang perempuan untuk mengalami kekerasan oleh pasangan laki-lakinya.

Peran ekonomi perempuan termasuk dalam komponen penghitung Indeks Pemberdayaan Gender yang diindikasikan melalui besarnya sumbangan pendapatan wanita. Walaupun masih terpaut cukup jauh dengan pendapatan pria, sumbangan pendapatan wanita terus mengalami peningkatan setiap tahunnya. Provinsi dengan sumbangan pendapatan wanita tertinggi adalah Nusa Tenggara Timur, sementara sumbangan pendapatan wanita terendah ada di provinsi Kalimantan Timur.

Sejalan dengan hal tersebut, pendapatan pekerja perempuan juga mengalami kenaikan dari tahun ke tahun. Namun demikian, pertumbuhan pendapatan pekerja perempuan cenderung melambat dalam 5 tahun terakhir dengan rata-rata pertumbuhan sebesar 7,28 persen per tahun (lihat Gambar 2).

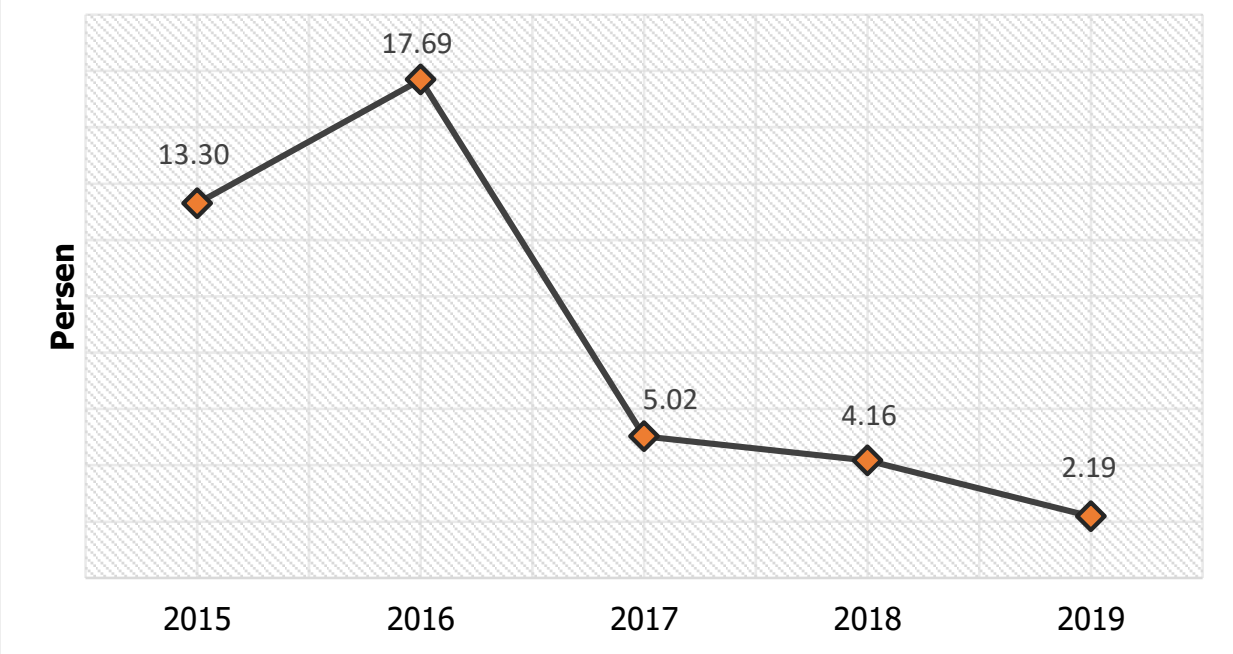

Sumber: Publikasi Keadaan Angkatan Kerja di Indonesia Agustus (diolah) 
Gambar 2. Pertumbuhan pendapatan pekerja perempuan di Indonesia, Tahun 2015-2019.

Kenaikan pertumbuhan pendapatan pekerja tertinggi terjadi pada tahun 2016. Sayangnya hal tersebut tidak berlangsung lama karena pada tahun-tahun berikutnya pertumbuhan pendapatan pekerja perempuan melambat secara konstan. Di antara 34 provinsi di Indonesia, yang mengalami pertumbuhan pendapatan pekerja perempuan tertinggi pada tahun 2016 ialah Bali, disusul oleh Kalimantan Timur, Jawa Timur, dan Banten.

Rata-rata pendapatan pekerja wanita tahun 2015-2108 bervariasi antar provinsi. Provinsi dengan rata-rata pendapatan pekerja wanita tertinggi ialah DKI Jakarta, sementara provinsi dengan rata-rata terendah ialah DI Yogyakarta.

\subsection{Analisis dan Pemodelan Pendapatan Pekerja Wanita di Indonesia}

Hasil pemilihan model terbaik terangkum dalam Tabel 1. Karena hasil uji Chow dan uji Hausman sama-sama menyimpulkan fixed effect model (FEM) adalah model yang tepat dibandingkan random effect model (REM), maka fixed effect model adalah model terpilih yang kemudian digunakan dalam regresi data panel pada penelitian ini.

Tabel 44. Hasil uji pemilihan model regresi data panel.

Uji

Chow (Pooled vs FEM)

Hausman (REM vs FEM)

BP Lagrange Multilier (Pooled Tolak $\mathrm{H}_{0}$
Keputusan

Tolak $\mathrm{H}_{0}$

Tolak $\mathrm{H}_{0}$ FEM
tepat

REM adalah model yang tepat

Kesimpulan

FEM adalah model yang tepat

FEM adalah model yang vs REM)

Selanjutnya, fixed effect model diperlakukan menjadi Seemingly Unrelated Regression dan diestimasi dengan feasible generalized least square karena terdapat masalah heteroskedastisitas dan cross-sectional correlation. Persamaan model sedikit dimodifikasi karena fixed effect mode/ mengizinkan adanya heteroginitas antarprovinsi. Setiap Provinsi pada model ini memiliki nilai intersepnya masing-masing. Berdasarkan hasil pengolahan didapatkan model berikut:

$$
\begin{aligned}
& \widehat{\mathrm{PP}}_{\mathrm{it}}=\left(-5.519,10+\mu_{\mathrm{i}}\right)-2,60 \mathrm{MAR}_{\mathrm{it}}+97,83 \mathrm{IPM}_{\mathrm{it}}+0,0022 \mathrm{PDRB}_{\mathrm{it}}+16,78 \mathrm{FW}_{\mathrm{it}} \\
& +0,07 \mathrm{AKP}_{\mathrm{it}}
\end{aligned}
$$

\begin{tabular}{|c|c|}
\hline i & $=$ provinsi \\
\hline $\mathrm{t}$ & $=$ tahun \\
\hline$\mu$ & $=$ efek heterogenitas (fixed effect) \\
\hline$\widehat{\mathrm{PP}}$ & $=$ pendapatan pekerja perempuan \\
\hline MAR & $=$ proporsi perempuan menikah muda \\
\hline IPM & $=$ IPM perempuan \\
\hline PDRB & $=$ Produk Domestik Regional Bruto \\
\hline FW & = proporsi perempuan bekerja \\
\hline AKP & = angkatan kerja perempuan \\
\hline
\end{tabular}

dimana:

Nilai heterogenitas tiap provinsi di Jawa-Bali disajikan pada Tabel 2. Nilai ini menunjukkan bahwa apabila seluruh variabel dalam peneltian ini sama untuk setiap provinsi, Jawa Timur yang akan menjadi provinsi dengan rata-rata pendapatan terendah sementara Papua Barat menjadi provinsi 
dengan rata-rata pendapatan tertinggi. Hal ini merupakan efek tetap yang berasal dari karakteristik provinsi tersebut.

Tabel 2. Nilai efek heterogenitas masing-masing provinsi di Indonesia.

$$
\text { Efek }
$$

Efek

Provinsi Heterogenitas Provinsi Heterogenitas

\begin{tabular}{|c|c|c|c|}
\hline Aceh & $-93,82$ & Nusa Tenggara Barat & $-16,41$ \\
\hline Sumatera Utara & $-971,19$ & Nusa Tenggara Timur & 466,49 \\
\hline Sumatera Barat & $-121,74$ & Kalimantan Barat & 602,20 \\
\hline Riau & $-533,59$ & Kalimantan Tengah & 637,76 \\
\hline Jambi & 71,58 & Kalimantan Selatan & 399,02 \\
\hline $\begin{array}{r}\text { Sumatera } \\
\text { Selatan }\end{array}$ & $-400,22$ & Kalimantan Timur & $-21,32$ \\
\hline Bengkulu & 220,72 & Kalimantan Utara & $1.326,23$ \\
\hline Lampung & $-88,74$ & Sulawesi Utara & 643,37 \\
\hline $\begin{array}{r}\text { Kep. Bangka } \\
\text { Belitung }\end{array}$ & 430,90 & Sulawesi Tengah & 270,73 \\
\hline Kep. Riau & 505,75 & Sulawesi Selatan & $-321,78$ \\
\hline Dki Jakarta & $-2.797,07$ & Sulawesi Tenggara & 344,46 \\
\hline Jawa Barat & $-1.785,21$ & Gorontalo & 999,85 \\
\hline Jawa Tengah & $-2.160,45$ & Sulawesi Barat & 691,60 \\
\hline Di Yogyakarta & $-1.215,64$ & Maluku & 641,62 \\
\hline Jawa Timur & $-3.112,65$ & Maluku Utara & 806,50 \\
\hline Banten & 389,76 & Papua Barat & $1.873,88$ \\
\hline Bali & $-349,93$ & Papua & 2667,32 \\
\hline
\end{tabular}

Secara umum, model yang terbentuk sudah baik. Dari pengujian kebaikan suai, diperoleh nilai adjusted $\mathrm{R}^{2}$ sebesar 0,9557. Hal ini berarti keenam variabel dapat menjelaskan 95,57 persen variasi pendapatan pekerja wanita dalam model regresi data panel, sementara sisanya dijelaskan oleh variabel lain di luar model. Selain itu, hasil pengujian signifikansi persamaan regresi secara simultan dengan uji $F$ juga menghasilkan $p$-value yang mendekati 0 dan lebih kecil dari taraf signifikansi 0,05 sehingga dapat disimpulkan bahwa minimal terdapat satu variabel bebas yang berpengaruh signifikan terhadap pendapatan pekerja perempuan. Nilai statistik uji Durbin-Watson ialah 2,28; nilai tersebut menunjukkan bahwa tidak ada autokorelasi dalam model regresi data panel. Uji asumsi klasik lain yang dibutuhkan untuk mengetahui apakah estimasi yang didapatkan bersifat BLUE atau Best, Linear, Unbiased Estimator juga menunjukkan hasil yang baik. Model yang terbentuk telah memenuhi asumsi normalitas dan nonmultikolinieritas. 
Hasil estimasi parameter model regresi data panel yang didapatkan dirangkum pada Tabel 3. Pengujian terhadap hipotesis penelitian telah dilakukan dengan uji $t$, untuk memeriksa apakah variabel bebas penelitian berpengaruh signifikan terhadap konsumsi listrik secara parsial.

Tabel 3. Hasil estimasi parameter model regresi data panel.

$\begin{array}{lrrrr}\text { Variabel } & \text { Koefisien } & \text { t-statistik } & p \text {-value } & \text { Keputusan } \\ \text { Konstanta } & -5519,098 & -2.716 & 0.0078 & \text { Tolak Ho } \\ \text { MAR } & -2,605 & -0.428 & 0.6697 & \text { Terima Ho } \\ \text { IPM } & 97,832 & 3.218 & 0.0018 & \text { Tolak Ho } \\ \text { PDRB } & 0,002 & 6.410 & 0.0000 & \text { Tolak Ho } \\ \text { FW } & 16,776 & 1.994 & 0.0489 & \text { Tolak Ho } \\ \text { AKP } & 0,067 & 0.351 & 0.7265 & \text { Terima } \mathrm{H}_{0}\end{array}$

Berdasarkan uji $t$ yang telah dilakukan, diperoleh hasil bahwa ada tiga variabel yang berpengaruh signifikan terhadap pendapatan pekerja wanita yakni IPM perempuan, PDRB, serta proporsi perempuan bekerja. Tiga variabel tersebut dan angka partisipasi kerja perempuan berpengaruh positif terhadap pendapatan pekerja perempuan, sementara proporsi perempuan yang menikah muda berpengaruh negatif. Nilai koefisien masing-masing variabel dapat dilihat pada Tabel 3, dengan interpretasi sebagai berikut:

- Perubahan satu persen pada proporsi perempuan yang menikah muda di suatu provinsi saat variabel lain tetap akan menurunkan rata-rata pendapatan pekerja wanita sebesar 2.605 rupiah.

- Perubahan satu satuan pada IPM perempuan di suatu provinsi saat variabel lain tetap akan meningkatkan rata-rata pendapatan pekerja wanita sebesar 97.832 rupiah.

- Perubahan satu trilliun rupiah pada PDRB di suatu provinsi saat variabel lain tetap akan meningkatkan rata-rata pendapatan pekerja wanita sebesar 2.000 rupiah.

- Perubahan satu persen pada proporsi perempuan bekerja di suatu provinsi saat variabel lain tetap akan meningkatkan rata-rata pendapatan pekerja wanita sebesar 16.776 rupiah.

- Perubahan seratus ribu orang angkatan kerja perempuan di suatu provinsi saat variabel lain tetap akan meningkatkan rata-rata pendapatan pekerja wanita sebesar 67 rupiah.

IPM perempuan menunjukkan kualitas pembangunan perempuan di suatu daerah. Semakin baik pembangunannya maka rata-rata pendapatan pekerja wanita juga semakin meningkat. PDRB menunjukkan jumlah nilai tambah yang dihasilkan oleh seluruh unit ekonomi di suatu daerah. Semakin besar nilai PDRB mengindikasikan bahwa keadaan ekonomi provinsi tersebut semakin bagus. Perekonomian yang baik pada akhirnya juga dapat meningkatkan tingkat pendapatan di daerah tersebut. Semakin tinggi proporsi perempuan bekerja mengindikasikan bahwa semakin rendahnya diskriminasi gender dalam ketenagakerjaan. Hal ini membuat pekerja perempuan lebih dihargai, salah satunya dengan meningkatnya tingkat pendapatan mereka.

\section{KESIMPULAN}

Pendapatan pekerja wanita di Indonesia mengalami kenaikan setiap tahunnya, dengan laju pertumbuhan yang cenderung menurun. Rata-rata pendapatan pekerja wanita tahun 2015-2108 bervariasi antar provinsi. Provinsi dengan rata-rata pendapatan pekerja wanita tertinggi ialah DKI Jakarta, sementara provinsi dengan rata-rata terendah ialah DI Yogyakarta. 
Analisis regresi data panel digunakan untuk memodelkan pendapatan pekerja wanita dari 34 provinsi di Indonesia periode 2015-2018. Model terpilih adalah fixed effect model, dengan persamaan sebagai berikut:

$$
\widehat{P P}_{i t}=\left(-5.519,10+\mu_{i}\right)-2,60 \mathrm{MAR}_{i t}+97,83 \mathrm{IPM}_{\mathrm{it}}+0,0022 \mathrm{PDRB}_{\mathrm{it}}+16,78 \mathrm{FW}_{\mathrm{it}}+0,07 \mathrm{AKP}_{\mathrm{it}}
$$

dengan PP mewakili pendapatan pekerja perempuan, MAR mewakili proporsi perempuan menikah muda, IPM mewakili IPM perempuan, PDRB mewakili Produk Domestik Regional Bruto, FW mewakili proporsi perempuan bekerja, serta AKP angkatan kerja perempuan. Dari pengujian kebaikan suai, diperoleh nilai adjusted $\mathrm{R}^{2}$ sebesar 0,9557. Hal ini berarti variabel independen dapat menjelaskan 95,57 persen variasi pendapatan pekerja wanita dalam model regresi data panel, sementara sisanya dijelaskan oleh variabel lain di luar model. Hanya IPM perempuan, PDRB, dan proporsi perempuan bekerja yang signifikan berpengaruh terhadap konsumsi listrik pada level 0,05 . Ketiganya berpengaruh positif terhadap variabel dependen. Nilai efek heterogenitas menunjukkan apabila seluruh variabel dalam peneltian ini bernilai sama untuk setiap provinsi, Jawa Timur akan menjadi provinsi dengan rata-rata pendapatan terendah sementara Papua Barat menjadi provinsi dengan rata-rata pendapatan tertinggi.

Penelitian lanjutan untuk topik pendapatan pekerja perempuan ini dapat dilakukan dengan data mikro. Agar lebih baik, penelitian selanjutnya dapat memodelkan tingkat pendapatan perempuan dengan variabel tingkat pendidikan terakhir, usia perkawinan pertama maupun lapangan kerja yang dipilih. Hali ini bertujuan untuk menghasilkan kesimpulan dan saran yang lebih aplikatif sehingga kebijakan yang dibuat bisa tepat sasaran.

\section{DAFTAR PUSTAKA}

Christoper, R., Chodijah, R., \& Yunisvita, Y. (2019). Faktor-faktor yang mempengaruhi pendapatan pekerja wanita sebagai Ibu rumah tangga. Jurnal Ekonomi Pembangunan. https://doi.org/10.29259/jep.v15i1.8820

Bhattacharjee, S., \& Goswami, B. (2020). Female Domestic Workers: Income Determinants and Empowerment Correlates-A Case Study. The Indian Journal of Labour Economics, 0123456789. https://doi.org/10.1007/s41027-020-00223-8

Febriani, W., \& Saleh, M. S. (2016). Determinan pendapatan added worker pada wanita menikah. Jurnal Ekonomi Pembangunan, 14(2), 64-68.

Greene, William H. (2012). Econometric analysis 7th Ed. Prentice Hall.

Huruta, A. D., Sasongko, G., \& Sari, P. I. A. (2019). The Determinant of Female Worker's Income in Central Java. JIEP,19(1).

Schieder, J., \& Gould, E. (2016). "Women's work" and the gender pay gap: How discrimination, societal norms, and other forces affect women's occupational choices-and their pay. 11.

Badan Pusat Statistik. (2015). Keadaan Angkatan Kerja di Indonesia Agustus 2015. Jakarta: Badan Pusat Statistik.

Badan Pusat Statistik. (2016). Keadaan Angkatan Kerja di Indonesia Agustus 2016. Jakarta: Badan Pusat Statistik.

Badan Pusat Statistik. (2017). Keadaan Angkatan Kerja di Indonesia Agustus 2017. Jakarta: Badan Pusat Statistik.

Badan Pusat Statistik. (2018). Keadaan Angkatan Kerja di Indonesia Agustus 2018. Jakarta: Badan Pusat Statistik.

Badan Pusat Statistik. (2019). Keadaan Angkatan Kerja di Indonesia Agustus 2019. Jakarta: Badan Pusat Statistik. 